\title{
Pituitary apoplexy
}

\section{WHAT IS PITUITARY APOPLEXY?}

Pituitary apoplexy is a rare endocrine emergency characterized by the sudden onset of severe headaches, vomiting visual abnormalities and pituitary dysfunction secondary to an acute hemorrhage or infarction within a pituitary adenoma.

\section{SUBJECTS AND METHODS}

We report a retrospective study from 2000 to 2014 of 23 cases with pituitary apoplexy. Their mean age was $38.7+/-10$ years, with a male to female ratio of $2: 1$.
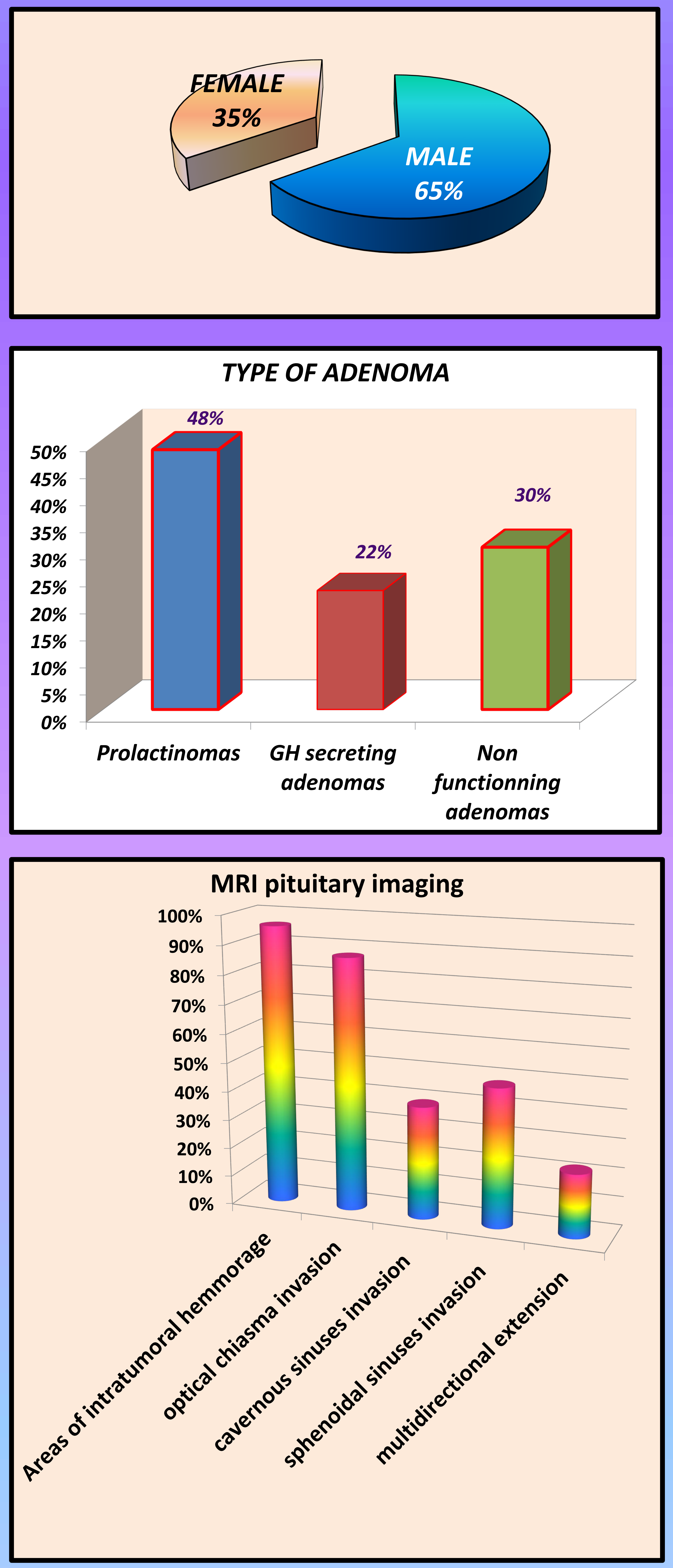

Bellarbi D, Azzoug S, Rabehi L, Terki B, Chentli F

Endocrine and Metabolic diseases department Bab El oued Hospital - Algiers - Algeria

\begin{tabular}{|c|c|c|c|c|}
\hline \multicolumn{5}{|c|}{ RESULTS } \\
\hline \multicolumn{5}{|c|}{ Apoplexy revealed an unknown adenoma in $74 \%$. } \\
\hline \multirow{2}{*}{$\begin{array}{c}\frac{\text { Type }}{\text { of adenoma }} \\
\underline{\text { dyen }}\end{array}$} & \multirow[t]{2}{*}{ Symptoms } & \multirow{2}{*}{$\frac{\text { Predisposing }}{\underline{\text { Factors }}}$} & $\frac{\text { Pituitary }}{\text { imaging }}$ & $\begin{array}{l}\text { Endocrine } \\
\text { evaluation }\end{array}$ \\
\hline & & & $\begin{array}{l}\text { showed } \\
\text { macroadenomas } \\
\text { in all cases. }\end{array}$ & $\begin{array}{l}\text { showed at least } \\
\text { one hormone } \\
\text { deficiency in } \\
92 \% .\end{array}$ \\
\hline $\begin{array}{l}\text { Prolactinomas } \\
48 \%\end{array}$ & $\begin{array}{l}\text { Frontal and } \\
\text { retro-orbital } \\
\text { Headaches } \\
92 \%\end{array}$ & Diabetes $31 \%$ & $\begin{array}{l}\text { Optical chiasma } \\
\text { invasion in } 87 \%\end{array}$ & $\begin{array}{l}\text { Gonadotroph } \\
\text { deficiency in } 70 \%\end{array}$ \\
\hline $\begin{array}{l}\text { GH secreting } \\
\text { adenomas } \\
22 \%\end{array}$ & $\begin{array}{l}\text { Visual } \\
\text { impairment } \\
78 \%\end{array}$ & $\begin{array}{l}\text { Bromocriptine } \\
\text { use in } 22 \%\end{array}$ & $\begin{array}{l}\text { Cavernous } \\
\text { sinuses invasion } \\
\text { in } 48 \%\end{array}$ & $\begin{array}{l}\text { corticotroph } \\
\text { deficiency in } 70 \%\end{array}$ \\
\hline \multirow{3}{*}{$\begin{array}{l}\text { Non } \\
\text { functionning } \\
\text { adenomas } \\
30 \%\end{array}$} & $\begin{array}{l}\text { Vomiting } \\
43 \%\end{array}$ & $\begin{array}{l}\text { Antithrombotic } \\
\text { medication } \\
4.3 \%\end{array}$ & $\begin{array}{l}\text { Sphenoidal } \\
\text { sinus invasion } \\
\text { in } 39 \%\end{array}$ & $\begin{array}{l}\text { Thyrotropic } \\
\text { deficiency in } 61 \%\end{array}$ \\
\hline & $\begin{array}{l}\text { Ocular Nerve } \\
\text { palsy } \\
\text { (diplopia } \\
\text { and ptosis) } \\
40 \%\end{array}$ & $\begin{array}{l}\text { Pregnancy in } \\
4.3 \%\end{array}$ & $\begin{array}{l}\text { Multidirectional } \\
\text { extension in } \\
22 \%\end{array}$ & \\
\hline & $\begin{array}{l}\text { Fever, } \\
\text { meningeal } \\
\text { irritation } \\
\text { signs, } \\
\text { rhinorea and } \\
\text { epistaxis } 8 \%\end{array}$ & & $\begin{array}{l}\frac{\text { Areas of }}{\text { intratumoral }} \\
\frac{\text { hemorrhage }}{\text { were evident on }} \\
\text { MRI in } 94 \% .\end{array}$ & $\begin{array}{l}\text { After the } \\
\text { apoplexy } \\
\text { episode: } \\
40 \% \text { of GH- } \\
\text { secreting } \\
\text { adenomas } \\
\text { normalized their } \\
\text { GH-lGF-1 levels } \\
27 \% \text { of } \\
\text { prolactinomas } \\
\text { normalized their } \\
\text { prolactin levels. }\end{array}$ \\
\hline
\end{tabular}

Six patients were treated with high dose glucocorticoids with complete neuroophtalmological recovery in $67 \%$.

\section{DISCUSSION}

In our study apoplexy reveals generally unknown adenomas. Male sex and functioning tumours, were major risk factors The majority of our patients had frontal and retro-orbital headaches associated to visual impairement as symptoms MRI pituitary imaging was the best diagnosis tool. It detects hemorraghe in the majority of the cases. All our patients with PA had a pituitary macroadenoma with important suprasellar extension, so large tumour size can be associated with a significantly increased risk of PA.

Diabetes, Bromocriptine, anti-thrombotic medication and pregnancy can be associated with risk of PA.

An event of PA lead to pituitary insufficiency at least in one hormone in the majority of our patients requiring substitution.

Our results confirm the findings of some previous studies in the literature.

\section{CONCLUSION}

Pituitary apoplexy is a rare life-threatening clinical syndrome caused by infarction or hemorrhage within a pituitary adenoma, once diagnosed a multidisciplinary team approach is mandatory in order to improve the outcome of this condition.
ALGIERS UNIVERSITY DEPARTEMENT OF MEDICINE
ENDOCRINE AND METABOLIC DISEASES DEPARTMENT BAB EL OUED HOSPITAL ALGIERS - ALGERIA 